Diklus: Jurnal Pendidikan Luar Sekolah, 2(2), September 2018 - 116

Aisyah Khoriunnisa

\title{
IMPLEMENTASI KURIKULUM PENDIDIKAN KEAKSARAAN DASAR KOMUNITAS ADAT TERTINGGAL SERTA IMPLIKASINYA TERHADAP KEBIJAKAN PENDIDIKAN KEAKSARAAN
}

\author{
Aisyah Khoirunnisaa dan Deni Kurniawan \\ Program Studi Pengembangan Kurikulum Sekolah Pascasarjana \\ Universitas Pendidikan Indonesia \\ e-mail: aisyah.khoirunnisaa@kemdikbud.go.id; denidoctor69@yahoo.co.id
}

\begin{abstract}
ABSTRAK
Penelitian ini dilatarbelakangi oleh keingintahuan terhadap bagaimana implementasi kurikulum pendidikan keaksaraan dasar komunitas adat tertinggal (KD-KAT) di Kampung Adat Cireundeu, dimana kurikulum yang digunakan mengacu kepada Peraturan Menteri Pendidikan dan Kebudayaan Republik Indonesia Nomor 86 tahun 2014 tentang Pedoman Penyelenggaraan Pendidikan Keaksaraan Dasar. Tujuan penelitian ini adalah untuk memperoleh informasi berbasis data empirik tentang implementasi kurikulum pendidikan KD-KAT di Kampung Adat Cireundeu serta implikasinya terhadap kebijakan kurikulum pendidikan keaksaraan. Implementasi kurikulum yang dimaksud meliputi tahap perencanaan, pelaksanaan, dan evaluasi. Penelitian menggunakan pendekatan kuantitatif dengan metode deskriptif melalui metode survei. Survei dilakukan di Kampung Adat Cireundeu Cimahi Jawa Barat. Populasi penelitian ini dilakukan kepada pengelola,tutor, dan warga belajar KD-KAT Komunitas Kampung Adat Cireundeu. Analisis data penelitian menggunakan Uji Chi-Square $\left(\chi^{2}\right)$. Hasil dari penelitian ini diharapkan dapat menggambarkan implementasi kurikulum pendidikan KD-KAT di Komunitas Adat Kampung Cireundeu serta bagaimana implikasinya terhadap kebijakan pendidikan keaksaaraan dasar secara umum.
\end{abstract}

Kata Kunci: implementasi, kurikulum, keaksaraan, cireundeu

\section{IMPLEMENTATION OF BASIC LITERACY EDUCATIONAL CURRICULUM THE MARGINALIZED INDEGENOUS COMMUNITY AND THE IMPLICATION OF THE LITERACY EDUCATION POLICY}

\author{
Aisyah Khoirunnisaa and Deni Kurniawan \\ Study Program Curriculum Development of Postgraduate Studies, \\ Indonesian University of Education (UPI) \\ e-mail: aisyah.khoirunnisaa@kemdikbud.go.id ; denidoctor_69@yahoo.co.id
}

\begin{abstract}
This research is motivated by the curiosity about how the implementation of the basic literacy education curriculum of marginalized indigenous communities in Cireundeu custom village, where the curriculum used refers to the Minister of Education and Culture of the Republic of Indonesia Number 86 of 2014 on Guidelines for the Implementation of Basic Literacy Education. The purpose of this study is to obtain empirical data-based information on the implementation of the basic literacy education curriculum of marginalized indigenous communities in custom village Cireundeu Cimahi and its implications for the literacy education curriculum policy. The implementation of the curriculum includes of the planning, implementation and evaluation phases. The research used quantitative approach with descriptive method through survey method. The survey was conducted in Custom Village Cireundeu Cimahi, West Java. The population of this study was conducted to the managers, teachers, and students of the basic literacy education of marginalized indigenous
\end{abstract}




\section{Diklus: Jurnal Pendidikan Luar Sekolah, 2(2), September 2018 - 117 Aisyah Khoriunnisa}

communities in custom village Cireundeu. Analysis of research data using Chi-Square Test $(\chi 2)$. The results of this study are expected to illustrate the implementation the basic literacy education of marginalized indigenous communities in custom village Cireundeu and how its implication to the policy of basic education.

\section{Keywords: implementation, curriculum, literacy, Cireundeu}

\section{PENDAHULUAN}

Pendidikan nasional harus menjamin pemerataan kesempatan pendidikan, peningkatan mutu dan relevansi, serta efisiensi manajemen pendidikan. Pemerataan kesempatan pendidikan melandasi pelaksanaan pendidikan di Indonesia melalui tiga jalur pendidikan sebagaimana dinyatakan dalam Undang-Undang No. 20 Tahun 2003 tentang Sistem Pendidikan Nasional pasal 13 ayat 1: "jalur pendidikan terdiri atas pendidikan formal, nonformal, dan informal yang dapat saling melengkapi dan memperkaya". Berikutnya pada pasal 26 ayat 1 menjelaskan bahwa, "pendidikan nonformal diselenggarakan bagi warga masyarakat yang memerlukan layanan pendidikan yang berfungsi sebagai pengganti, penambah dan atau pelengkap pendidikan formal dalam rangka mendukung pendidikan sepanjang hayat". Pendidikan non formal berperan dalam mengembangkan peserta didik dengan penekanan pada penguasaan pengetahuan dan keterampilan fungsional pengembangan sikap dan kepribadian profesional, yang dapat diselenggarakan melalui pendidikan kecakapan hidup, pendidikan anak usia dini, pendidikan kesetaraan, pendidikan keaksaraan, pendidikan kursus dan pelatihan, serta pendidikan lain di luar pendidikan formal yang bertujuan untuk mengembangkan kemampuan peserta didik (Kusnadi, 2005). Salah satu bentuk penyelenggaraan pendidikan non formal di Indonesia yang masih terus dikembangkan hingga saat ini adalah program pendidikan keaksaraan.

Pendidikan keaksaraan merupakan bentuk layanan pendidikan untuk membelajarkan warga masyarakat buta aksara, agar mampu memiliki kemampuan menulis, membaca, berhitung dan menganalisa serta berorientasi kepada kehidupan sehari-hari dengan memanfaatkan potensi yang ada di lingkungan sekitar sehingga mutu dan taraf hidup warga belajar dan masyarakat dapat meningkat. Terkait sasaran program Pendidikan Keaksaraan di Indonesia, berdasarkan hasil pendataan yang dilakukan oleh Pusat Data dan Statistik Pendidikan (PDSP) Kemdikbud, terjadi penurunan jumlah penduduk buta aksara pada usia 15-59 tahun dari tahun ke tahun. Di tahun 2016 populasi penduduk usia 15-59 tahun 164.662.200 orang, penduduk buta aksara usia 15-59 tahun adalah 3.416.693 orang sehingga diperoleh persentase Buta Aksara Nasional (usia 15-59 tahun) sebesar 2,07 \% (PDSP Kemdikbud, 2017). Hal ini menunjukkan penurunan dari tahun sebelumnya, yaitu $3,43 \quad \% \quad$ (PDSP Kemdikbud, 2015).

Buta aksara dalam usia produktif (15-59 tahun) merupakan salah satu faktor penghambat dalam mutu dan kualitas sumber daya manusia di Indonesia. Oleh karena itu, Direktorat Pembinaan Keaksaraan dan kesetaraan Kemdikbud membuat Kebijakan Pendidikan Keaksaraan merancang program-program yang tidak hanya mendidik masyarakat menjadi melek aksara (bisa membaca, menulis, dan berhitung) saja, tetapi juga pendidikan keaksaran dapat mengembangkan kemampuan individu agar mampu mengatasi permasalahan kehidupannya melalui keaksaraan. Saat ini program Pendidikan Keaksaraan terdiri dari tiga program, yaitu pendidikan keaksaraan dasar, pendidikan keaksaraan lanjutan, dan Pengembangan Pendidikan Multikeaksaraan. 


\section{Diklus: Jurnal Pendidikan Luar Sekolah, 2(2), September 2018 - 118 Aisyah Khoriunnisa}

Kurikulum untuk Pendidikan Keaksaraan Dasar diatur dalam Peraturan Menteri Pendidikan dan Kebudayaan Republik Indonesia Nomor 86 tahun 2014 tentang Pedoman Penyelenggaraan Pendidikan Keaksaraan Dasar. Kerangka dasar dan struktur kurikukulum Pendidikan keaksaraan dasar diuraikan dalam bentuk kompetensi inti dan kompetensi dasar beserta kelengkapakannya yaitu silabus, bahan ajar, pedoman pembelajaran, serta sistem dan prosedur penilaian. Pelaksanaan Pendidikan Keaksaraan Dasar sebanyak 114 jam pelajaran dimana 1 (satu) jam pelajarannya adalah 60 menit, dan terdiri atas keterampilan membaca dan menulis sebanyak 80 jam dan keterampilan berhitung sebanyak 34 jam. Penyelenggaraan pendidikan keaksaraan dilaksanakan berdasarkan kurikulum yang disusun oleh Kementerian melalui Direktorat Jenderal dan/atau unit terkait dan dikembangkan lebih lanjut oleh Dinas Pendidikan Provinsi/Kabupaten/Kota dan satuan pendidikan nonformal yang menyelenggarakan pendidikan keaksaraan dasar sesuai dengan jenis dan kelompok program pendidikan keaksaraan dan peserta didik.

Implementasi kurikulum dalam pendidikan keaksaraan dasar komunitas adat terpencil baik dalam tahap perencanaan, pelaksanaan, dan evaluasi harus mempertimbangkan latar belakang budaya, pekerjaan, ekonomi, hingga pendidikan peserta didik di komunitas adat tersebut. Dalam disertasinya, Mahu (2011) menyatakan bahwa kehidupan komunitas adat terpencil masih tradisional, kondisi geografis terisolasi bahkan sulit dijangkau, tingkat pendidikan warga KAT pada umumnya buta aksara, serta apabila ada atau pernah dilakukan program pendidikan keaksaraan baik tingkat dasar maupun lanjutan bagi KAT biasanya dibatasi dalam hal jumlah peserta didik dan juga mengunakan materi belajar keaksaraan umum yang tidak sesuai kebutuhan dan potensi daerah KAT tersebut.

Salah satu Komunitas Adat yang ada di Jawa Barat adalah Komunitas Adat Kampung Cireundeu. Kurikulum yang digunakan pada KD-KAT mengacu kepada Peraturan Menteri Pendidikan dan Kebudayaan Republik Indonesia Nomor 86 tahun 2014 tentang Pedoman Penyelenggaraan Pendidikan Keaksaraan Dasar.

Kurikulum sebagai alat atau instrumen harus mampu mempersiapkan generasi bangsa dalam mencapai tujuan pendidikan nasional. Kurikulum memiliki pengaruh terhadap seluruh kegiatan pendidikan. Mengingat pentingnya kurikulum dalam pendidikan dan kehidupan manusia, maka penyusunan kurikulum tidak bisa dilakukan secara sembarangan. Penyusunan kurikulum membutuhkan konsep-konsep yang kuat, yang didasarkan pada hasil-hasil pemikiran dan penelitian yang mendalam. Penyusunan kurikulum yang tidak didasarkan pada konsep yang kuat dapat berakibat fatal terhadap kegagalan pendidikan itu sendiri. Dengan sendirinya, akan berakibat pula terhadap kegagalan proses pembentukan manusia Indonesia yang bermoral baik, tangguh, berkarakter, serta berkehidupan sosial yang sehat. Ornstein \& Hunkins (2017: 257) menyatakan bahwa "successful curriculum implementation results from careful planning, which focuses on three factors: people, programs, and process". Sejalan dengan itu, implementasi kurikulum yang sesuai dengan rencana tentunya memerlukan bebeberapa kesiapan terutama pada faktor kesiapan guru sebagai pelaksana kurikulum serta didukung oleh faktor lainnya (Rusman, 2009).

Berikut definisi implementasi kurikulum menurut beberapa ahli:

1. Miller dan Seller (1985) menyebutkan bahwa: "in some case implementation has been identified with instruction". Dapat diartikan bahwa implementasi 


\section{Diklus: Jurnal Pendidikan Luar Sekolah, 2(2), September 2018 - 119 Aisyah Khoriunnisa}

sebagai aktualisasi kurikulum tertulis dalam bentuk pembelajaran.

2. Susilana dan Rusman (2015) berpendapat bahwa implementasi kurikulum dapat ditinjau dari dua hal, yaitu: (1) implementasi kurikulum sebagai teknis dari sebuah tindakan terhadap sebuah alat/instrumen dan (2) implementasi kurikulum sebagai praktis. Implementasi sebagai teknis, artinya implementasi dilihat dari aturan yang sebagaimana mestinya dijalankan baik dari segi perencanaan, pelaksanaan dan evaluasi. Sedangkan jika implementasi dilihat sebagai praktis yaitu implementasi didasarkan pada pengalaman dan situasi yang riil dialami di dalam kelas, komunikasi yang nyata terjadi diantara guru dan siswa.

3. Fullan dalam Wahyudin (2014, h.94) mendefinisikan "implementasi kurikulum sebagai penerapan atau pelaksanaan program kurikulum yang telah dikembangkan dalam tahap sebelumnya, kemudian diujicobakan dengan pelaksanaan dan pengelolaan yang disesuaikan dengan situasi dan kondisi lapangan dan karakteristik peserta didik baik perkembangan intelektual, emosional serta fisik".

Berdasarkan beberapa definisi tersebut diatas, maka implementasi kurikulum dapat diartikan sebagai aktivitas dari pelaksanaan sebuah dokumen rencana dan kemudian dituangkan dalam bentuk pembelajaran dengan mempertimbangkan faktor pendukung dan penghambatnya dalam keadaan sebenarnya saat pembelajaran terjadi. Tentunya kurikulum yang diimplementasikan dalam sebuah satuan pendidikan memerlukan strategi yang tepat dalam mengelola berbagai hal dan juga pihak-pihak yang terlibat dalam implementasi kurikulum baik pada tahap perencanaan, pelaksanaan, maupun penilaian kurikulum dengan tidak meninggalkan ciri khas serta nilai-nilai budaya di Komunitas Kampung Adat Cireundeu. Oleh karena itu, penulis tertarik untuk melihat bagaimana pelaksanaan implementasi kurikulum pendidikan Keaksaraan Dasar Komunitas Adat tertinggal di Masyarakat Adat Kampung Cireundeu.

\section{METODE}

Pendekatan penelitian yang digunakan adalah pendekatan kuantitatif dengan metode deskriptif melalui studi survei. Metode ini dipilih karena tepat digunakan untuk mendeskripsikan fenomena dari implementasi kurikulum pendidikan KD-KAT apa adanya. Penelitian deskriptif tidak memberikan perlakuan, manipulasi atau pengubahan pada variabel-variabel bebas, tetapi menggambarkan sebuah keadaan apa adanya. Tanpa adanya penelitian, setiap kegiatan, kejadian, dan keadaan berjalan sebagaimana adanya (Sukmadinata, 2012, hlm. 73-74).

Dalam penelitian ini terdiri dari variabel tunggal yaitu implementasi kurikulum keaksaraan dasar komunitas adat tertinggal dan 5 (lima) sub variabel seperti yang tercantum sebagai rumusan masalah penelitian yaitu Perencanaan Kurikulum, Pelaksanaan Kegiatan Pembelajaran, evaluasi hasil belajar, faktor pendukung dan penghambat implementasi kurikulum, serta implikasi terhadap kebijakan pendidikan keaksaraan.

Teknik pengumpulan data dilakukan melalui kuosioner, wawancara serta studi dokumentasi. Sebelum dilakukan analisis data, data hasil penelitian dari lokasi penelitian dibuat tabulasi data yang berisi jawaban responden dari berbagai sub variabel yang akan disajikan. Kemudian diuji normalitasnya dengan menggunakan One-Sample Kolmogorov-Smirnov Test. Berdasarkan hasil uji normalitas dapat disimpulkan bahwa data hasil penelitian memenuhi persyaratan untuk dilakukan analisis lebih lanjut dengan persentase. Dari perhitungan data yang diperoleh kemudian secara deskriptif. Persentase 
yang dinyatakan dalam bentuk angka dinyatakan dalam bentuk tafsiran yang menunjukkan pada pernyataan keadaan atau ukuran kualitas. Tafsiran ditentukan berdasarkan skala kategori dengan cara membaginya menjadi tiga kategori yaitu : Baik, Cukup, dan Kurang. Untuk analisis data dari hasil wawancara dilakukan dengan mendeskripsikan data tersebut berdasarkan masalah dan tujuan penelitian, sehingga dilakukan analisis secara kualitatif.

\section{HASIL DAN PEMBAHASAN}

Data hasil temuan penelitian diungkap dan dibahas secara terperinci, berdasarkan kuesioner dari responden serta informasi dari hasil wawancara sesuai dengan tujuan dari penelitian ini adalah untuk memperoleh gambaran mengenai implementasi kurikulum pendidikan keaksaraan dasar komunitas adat tertinggal di Masyarakat Cireundeu yaitu pada sub variabel : 1) perencanaan Kurikulum Pendidikan Keaksaraan Dasar Komunitas Adat Tertinggal, pelaksanaan kegiatan pembelajaran pada pendidikan Keaksaraan Dasar Komunitas Adat Tertinggal, 3) Evaluasi hasil belajar
Cireundeu terhadap kebijakan pendidikan keaksaraan dasar di Indonesia.

Dari hasil perhitungan data yang diperoleh, dapat diketahui nilai $\mathrm{P}$ secara keseluruhan adalah sebesar 74,36 \% yang berada dalam kategori "cukup" yang kemudian apabila diuraikan untuk setiap sub variabel dapat dilihat pada tabel 4.1 Rekapitulasi pada tabel 4.1. tersebut diperoleh dari hasil pengolahan data kuesioner baik untuk responden tutor maupun warga belajar.

Tabel 4.1 Rekapitulasi Data Nilai P secara Keseluruhan

\begin{tabular}{|c|c|c|}
\hline Sub Variabel & $\begin{array}{c}\mathbf{P} \\
(\%)\end{array}$ & Kategori \\
\hline 1. Perencanaan & 67.92 & Kurang \\
\hline 2. Pelaksanaan & 77.14 & Cukup \\
\hline 3. Penilaian & 76.70 & Cukup \\
\hline $\begin{array}{l}\text { 4. Faktor } \\
\text { Pendukung } \\
\text { dan } \\
\text { Penghambat }\end{array}$ & 75.68 & Cukup \\
\hline
\end{tabular}
batang akan terlihat pada bagan 4.1

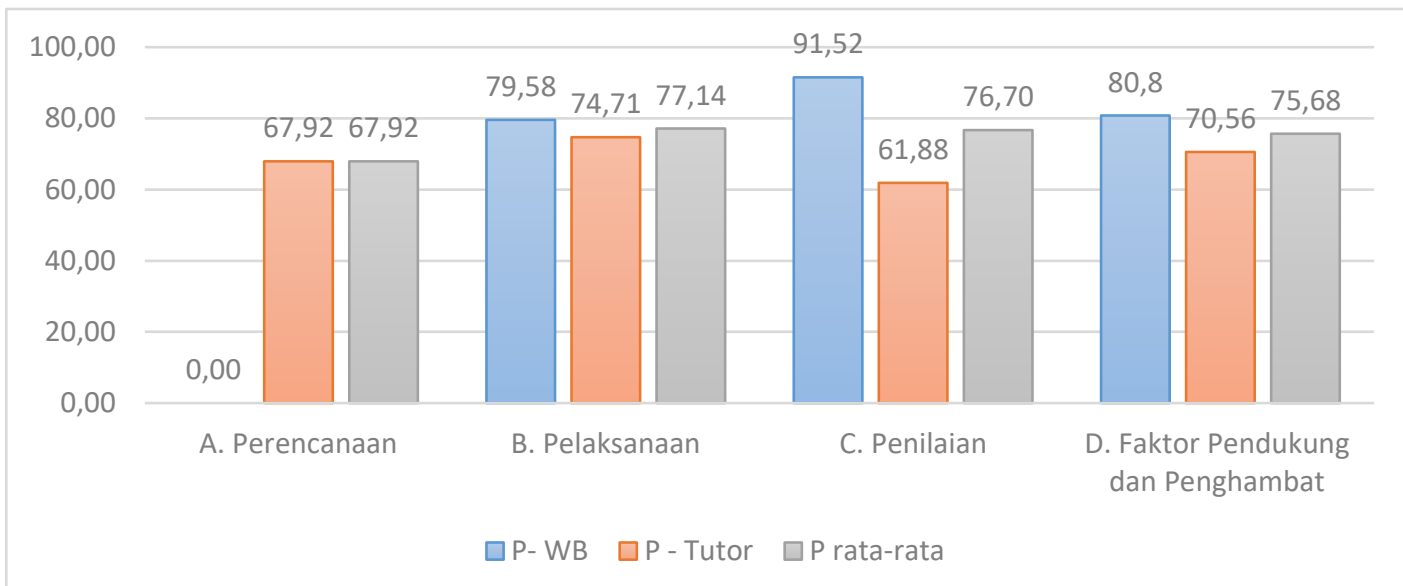

pada Kurikulum Pendidikan Keaksaraan Dasar Komunitas Adat Tertinggal, 4) Faktor pendukung dan penghambat implementasi Kurikulum Pendidikan Keaksaraan Dasar Komunitas Adat Tertinggal, serta 5) Implikasi Kurikulum Pendidikan Keaksaraan Dasar Komunitas Adat Tertinggal di Masyarakat Adat
Hasil dari studi dokumentasi, seperti: silabus, RPP, Bahan Ajar, Instrumen penilaian, pelaporan Hasil Belajar, dan Data Warga belajar dalam keadaan lengkap.

Dari hasil pengolahan data, implementasi kurikulum pendidikan keaksaraan dasar komunitas adat tertinggal 


\section{Diklus: Jurnal Pendidikan Luar Sekolah, 2(2), September 2018 - 121 Aisyah Khoriunnisa}

berada dalam kategori "cukup" (lihat tabel 4.1) pada keempat sub variabel yang diukur melalui perolehan data kuesioner. Ornstein \& Hunkins (2017, hlm. 277) menyebutkan bahwa untuk menerima sebuah inovasi, seorang guru perlu melihat kualitas, nilai, dan kepraktisannya. Dalam banyak kasus, pendidik tidak punya waktu untuk melaksanakan saran perbaikan sehingga terkadang kurikulum diterapkan secara sembarangan, padahal bisa saja dapat dilaksanakan dengan baik jika mereka yang bertanggung jawab dalam implementasi kurikulum, staf bagian kurikulum misalnya, dapat memastikan bahwa materi yang diperlukan tersedia bagi para guru. Penyelenggaraan pendidikan keaksaraan dasar bagi komunitas adat di Cireundeu adalah hal baru sehingga sangat dimungkinkan penyelenggara ataupun tutor belum mempunyai kompetensi yang sesuai dalam hal prinsip-prinsip kurikulum tetapi kompetensi dalam konten sejarah serta budaya lokal Cireundeu serta semangat mereka untuk bisa belajar aksara Indonesia terbilang tinggi. Data ini didukung pula dari hasil wawancara terhadap pengelola mengenai motivasi dan kompetensi. Berikut pembahasan berdasarkan hasil temuan untuk masing-masing sub variabel.

Penelitian ini bermaksud mengungkap implementasi kurikulum pada pada pendidikan keaksaraan dasar komunitas adat tertinggal di masyarakat adat Cireundeu. Implementasi kurikulum yang dimaksud dalam penelitian ini seperti yang diuraikan dalam definisi operasional adalah berupa aktivitas pelaksanaan dari dokumen tertulis pendidikan keaksaraan dasar dan kemudian dituangkan dalam bentuk pembelajaran pada kelompok sasaran keaksaraan dasar, meliputi aspek perencanaan, pelaksanaan, serta evaluasi hasil belajar. Aspek perencaaan meliputi kurikulum, silabus dan RPP. Aspek pelaksanaan meliputi metode pembelajaran, teknik, serta media belajar yang digunakan tutor saat pembelajaran.
Aspek evaluasi hasil belajar meliputi teknik penilaian pembelajaran.

Pada bagian perencanaan kurikulum pendidikan keaksaraan dasar komunitas adat tertinggal berada dalam kategori "cukup" dengan nilai P sebesar $67.92 \%$. Nilai ini diperoleh dari perolahan data kuesioner terhadap tutor. Tetapi dalam hasil pengolahan data melalui kuesioner untuk setiap indikatornya diperoleh nilai $\mathrm{P}$ berbedabeda. Perencanaan merupakan sebuah proses atau cara berpikir yang dapat membantu memperoleh hasil yang diharapkan sehingga dari perencanaan yang sudah disusun dapat dipilih alternatif yang ada. Kaufmann (1979) dalam Idi (2014, hlm. 188-189) mengungkapkan langkah-langkah perencanaan yang baik yaitu:

1) Mengidentifikasi masalah berdasarkan kebutuhan,

2) Menentukan syarat dan alternatif pemecahannya,

3) Memilih strategi pemecahannya,

4) Menentukan identifikasi hasil melalui penilaian, serta

5) Melakukan revisi pada langkahlangkah yang dilalui (apabila dianggap perlu)

Bagi pendidik atau tutor, langkahlangkah Kaufmann berguna dalam merencanakan dan mengembangkan langkah-langkah dalam pembelajaran. Indikator identifikasi kebutuhan berada dalam kategori "cukup", hal ini dapat dikonfirmasi melalui wawancara terhadap pengelola pendidikan keaksaraan dasar komunitas adat tertinggal bahwa sebagai langkah awal dari penyelenggaraan pendidikan keaksaraan dasar, pengelola melakukan sosialisasi dan identifikasi untuk mencari calon tutor dan peserta didik.

Kegiatan yang dilakukan sebagai rangkaian kegiatan identifikasi adalah sebagai berikut :

1) Sosialisasi program pendidikan keaksaraan dasar komunitas adat 
terpencil kepada calon tutor yang merupakan perwakilan dari 10 titik sasaran program di lingkungan masyarakat Cireundeu. Sosialisasi program dilaksanakan di Bale Saresehan Masyarakat Cireundeu.

2) Penjaringan calon peserta didik dengan memberdayakan para tutor yaitu setiap satu orang tutor diharapkan dapat mengajak minimal 10 (sepuluh) warga masyarakat di lingkungannya untuk menjadi peserta program. Mengajak warga masyarakat tentunya dilakukan secara persuasif serta berdasarkan kriteria calon warga belajar yang sudah ditentukan yaitu sebagai berikut (1) warga masyarakat komunitas adat terpencil; (2) berusia 15 tahun ke atas; (3) belum memiliki kemampuan membaca, menulis dan berhitung dalam bahasa indonesia dan bahasa cacarakan, serta (4) Bersedia untuk mengikuti program pendidikan keaksaraan komunitas khusus.

3) Penyusunan bahan ajar dan rencana pelaksanaan pembelajaran (RPP). Kegiatan penyusunan bahan ajar dan RPP dilakukan melalui pertemuan tutor dan pengelola. Masing-masing tutor ditugaskan untuk menyusun bahan ajar dan RPP yang sederhana.

Penyusunan bahan ajar dan RPP ditekankan pada upaya melatih kemampuan membaca, menulis dan berhitung masyarakat sekaligus pelestarian budaya khas cireundeu khususnya bahasa cacarakan.

Pada indikator berikutnya, yaitu perumusan tujuan pembelajaran dan bahan/materi ajar. Keduanya berada dalam kategori baik. Perumusan tujuan pembelajaran disesuaikan dengan hasil identifikasi dan kemudian akan dikembangkan ke dalam silabus dan RPP. Tujuan pembelajaran merupakan suatu pernyataan yang jelas dan menunjukkan penampilan atau keterampilan peserta didik tertentu yang diharapkan dapat dicapai sebagai hasil belajar.
Pelaksanaan

Kegiatan

Pembelajaran Pendidikan Keaksaraan Dasar Komunitas Adat Tertinggal, kurikulum yang telah tersusun di tahap perencanaan tentu haruslah dapat diimplementasikan. Pada bagian Sub variabel pelaksanaan kurikulum pendidikan keaksaraan dasar komunitas adat tertinggal berada dalam kategori cukup dengan nilai $\mathrm{P}$ sebesar 77,14\%. Nilai ini diperoleh dari perolahan data kuesioner terhadap tutor dan warga belajar. Tetapi dalam hasil pengolahan data melalui kuesioner untuk setiap indikatornya baik dari responden tutor maupun responden warga belajar keduanya diperoleh kategori baik.

\section{Pelaksanaan pembelajaran adalah proses berlangsungnya kegiatan} pembelajaran berupa interaksi antara peserta belajar dengan tutor atau antara peserta belajar itu sendiri. Dalam kegiatan pembelajaran ada beberapa tingkah pokok yang harus dilalui yaitu: evaluasi awal, pelaksanaan pembelajaran, evaluasi akhir dan tindak lanjut. Secara umum dalam pelaksanaan pembelajaran terdapat komponen-komponen yang bisa mendukung pencapaian tujuan dari pembelajaran. Komponen pertama adalah metode yang digunakan dalam pembelajaran. Kedua, bahan dan media belajar serta teknik yang dipergunakan dalam pembelajaran. Ketiga, adalah kegiatan-kegiatan yang dilakukan untuk menghindari kejenuhan dalam pembelajaran. Peranan guru pada tahapan ini sangatlah penting, oleh karena itu dalam pertanyaan/pernyataan kuesioner lebih banyak bertanya tentang kegiatan apa saja yang dilakukan oleh tutor.

Indikator identifikasi dengan melakukan penilaian awal berada dalam kategori Baik. Penilaian awal (pre-test) dilakukan sebelum pembelajaran dimulai yang bertujuan untuk mengetahui kemampuan awal peserta didik mengenai materi pelajaran yang akan diajarkan. Soal-soal tes dipersiapkan terlebih dahulu 


\section{Diklus: Jurnal Pendidikan Luar Sekolah, 2(2), September 2018 - 123 Aisyah Khoriunnisa}

oleh tutor pada tahap merencanakan pembelajaran.

Indikator kegiatan pembukaan pembelajaran kuesioner tutor memperoleh nilai $\mathrm{P}$ sebesar 81,67\% berada dalam kategori baik kuesioner untuk warga belajar memperoleh nilai $\mathrm{P}$ sebesar 79,53 \% serta berada dalam kategori baik. Dalam hal ini tutor melakukan kegitatan pembelajaran sebagaimana mestinya seperti membuka pelajaran dengan menyebutkan tujuan pembelajaran yang akan dicapai, membuka pelajaran secara menarik sehingga warga belajar termotivasi untuk terus mengikuti pembelajaran dari awal hingga akhir, memberikan acuan akan materi pembelajaran yang akan dipelajari, serta mengaitkan materi pembelajaran yang sudah warga belajar pahami dengan materi yang akan dipelajari, serta tutor memberikan penilaian awal sebelum pembelajaran dimulai. Baik pada kuesioner warga belajar dan tutor samasama berada dalam kategori baik.

Indikator kesesuaian pelaksanaan pembelajaran sesuai dengan RPP berada dalam kategori "cukup". Penyesuaian RPP saat pelaksanaan sepertinya terjadi saat pembelajaran. Indikator berikutnya adalah pengelolaan kegiatan inti yang sesuai dengan karakteristik pendidikan keaksaraan (kontekstual, kooperatif \& kolaboratif, andragogik, tematik, penekananan kepada pembelajaran aktif, inovatif, kreatif dan menyenangkan) baik pada responden tutor maupun warga belajar berada dalam kategori kurang. Meskipun begitu dalam pelaksanaannya, tutor sering juga mempergunakan pendekatan pembelajaran kontekstual yaitu menghubungkan materi pembelajaran dengan situasi sehari-hari. Untuk lebih memotivasi peserta didik dalam mengikuti pembelajaran, dalam waktu-waktu tertentu peserta didik diberi kesempatan untuk melakukan praktek keterampilan yang berkenaan dengan makanan khas, seni budaya, maupun hal yang ada kaitannya dengan acara-acara khusus komunitas adat. Jenis praktek keterampilan yang dipraktekkan peserta didik disesuaikan dengan nama kelompoknya. Ada kelompok yang praktek membuat makanan khas seperti awug, gondang, rangining, peuyeum mutiara, adapula yang praktek berkaitan dengan nilai/symbol yang menunjukkan identitas komunitas adat cireundeu, misalnya tingkeban, tembang-tembang, asal usul Cireundeu, mulud, dan jampana.

Dalam pelaksanaan pembelajaran tidak lepas dari penggunaan strategi pembelajaran. Strategi dalam pembelajaran adalah penetapan keseluruhan aspek yang berkaitan dengan pencapaian tujuan belajar, termasuk penyusunanan perencanaan, pelaksanaan kegiatan pembelajaran dan penilaian proses serta hasil belajar. Rusman (2009, hlm.75) mengatakan bahwa "implementasi kurikulum seharusnya menempatkan pengembangan kreativitas siswa lebih dari penguasaan materi". Strategi pembelajaran yang dapat digunakan dalam kegiatan pembelajaran ada yang berpusat kepada tutor (learning centered) dan ada yang berpusat kepada peserta belajar (student centered).

Pembelajaran bagi orang dewasa seperti yang dikatakan oleh Lyra Srinivasan (dalam Sudjana, 2000, hlm. 73) yaitu: (a) pendekatan yang berpusat pada masalah, (b) pendekatan proyektif, dan (c) pendekatan aktualisasi diri. Pendekatan yang berpusat pada masalah, salah satunya ditunjukkan dengan belajar menyusun atau menggambarkan peta masyarakat Cireundeu. Pendekatan ini bertujuan supaya warga belajar dapat meningkatkan keterampilan menulis melalui menggambar garis dan simbol. Kemudian tutor menggunakan, hasil gambar peta warga belajar untuk membantu mereka berdiskusi dan menganalisa informasi tentang situasi pemukiman, tempat tinggal warga belajar (terlampir dalam silabus). 
Rusman dan Laksmi Dewi (Tim MKDP Kurikulum dan Pembelajaran, 2016, hlm. 190) menyatakan bahwa pendekatan pembelajaran adalah suatu upaya menghampiri makna pembelajaran melalui suatu cara pandang dan pandangan tertentu; atau aplikasi suatu cara pandang dan pandangan tertentu dalam memajami makna pembelajaran. Dengan demikian, pendekatan pembelajaran dapat diartikan sebagai suatu cara pandang atau titik tolak yang digunakan oleh pendidik terhadap proses pembelajaran dan akan mempengaruhi pemilihan strategi dan metode pembelajaran selanjutnya.

Sementara itu, dalam menetapkan metode yang akan dilakukan dalam pembelajaran tidak lepas dari strategi yang akan digunakan. Metode pembelajaran yang bisa dipergunakan oleh tutor dalam pelaksanaan pembelajaran pendidikan keaksaraan untuk warga belajar pemula diantaranta metode abjad (alphabetic method), metode kata kunci, metode global (the sentence method) metode suku kata (sillabic method), metode SAS (Struktur Analitik Sintetik) dan metode asosiasi, huruf dan angka yang diperkenalkan melalui metode ini dikaitkan dengan sesuatu yang telah dikenal oleh warga belajar (Kusnadi, 2005: 216). Sejalan pulan denga karakteristik pembelajaran pendidikan keaksraan yaitu tematik dimana tema-tema diambil dari lingkungan keseharian dan dekat dengan kehidupan warga belajar.

Hal ini sejalan dengan metode belajar yang dilakukan tutor lebih banyak menggunakan metode latihan dalam membantu peserta didik memahami, menguasai dan membiasakan kemampuan membaca, menulis dan berhitung dalam bahasa Indonesia dan bahasa Cacarakan. Latihan yang dimaksud adalah mengkondisikan peserta didik untuk lebih banyak mencoba mengucapkan huruf, kata, kalimat sederhana, dan menulis huruf/kata/kalimat sederhana. Dengan metode ini diharapkan peserta didik dapat lebih cepat mengenal, mengingat dan membuat tulisan baik dalam Bahasa Indonesia maupun dalam bahasa Cacarakan. Proses pembelajaran juga dilakukan dengan metode peer teaching atau tutor sebaya, ini dilakukan setelah warga belajar yang mengikuti beberapa kali pertemuan pembelajaran, dan dianggap telah memiliki kemampuan dasar dalam berbahasa Indonesia dan bahasa Cacarakan. Warga belajar yang dianggap telah memiliki kemampuan dasar dibanding warga belajar yang lain akan ditugaskan untuk membantu peserta lain yang belum terampil. Tutor sebaya digunakan untuk membantu warga belajar yang lambat atau untuk memberikan tambahan kemampuan bagi semua warga belajar yang masih lemah dalam membaca, menulis dan berhitung dalam bahasa Indonesia.

Pada indikator pengelolaan kegiatan inti sesuai dengan karakteristik pendidikan keaksaraan (kontekstual, kooperatif \& kolaboratif, andragogik, tematik, penekananan kepada pembelajaran aktif, inovatif, kreatif dan menyenangkan) yang diolah dari tutor berada pada kategori "kurang" dengan nilai P $70 \%$.

Dengan perencanaan pembelajaran yang diatur sedemikian mengikuti Permendikbud idealnya pada indikator ini berada dalam kategori baik, tetapi hasil presentase tidak berkata demikian. Tutor sebagai kunci dalam pelaksanaan implementasi kurikulum yang berpengaruh besar. Perencanaan yang baik tetapi pada saat pelaksanaan tidak dijalankan sepenuhnya sesuai dengan rencana yang terdapat dalam RPP. Meskipun apabila tutor melakukan perubahan strategi tidak menyalahi prinsip pembelajaran pendidikan keaksaraan dasar, yaitu fleksibel, namun apabila terlalu banyak penyesuaian dalam 


\section{Diklus: Jurnal Pendidikan Luar Sekolah, 2(2), September 2018 - 125 Aisyah Khoriunnisa}

pelaksanaan maka hal ini dapat dijadikan bahan masukan dalam perbaikan kurikulum yang telah disusun untuk diimplementasikan pada kelompok berkutnya.

Terakhir, Indikator penutupan pembelajaran berada dalam kategori "cukup" dengan nilai P sebesar 70,8\% bagi responden tutor sedangkan bagi responden warga belajar indikator ini berada dalam kategori "baik" dengan nilai $\mathrm{P}$ sebesar $82,8 \%$. Hal ini ditunjukan dengan beberapa pernyataan dalam kuesioner bahwa tutor melakukan revieu yang sudah dipelajari di akhir pertemuan, tutor membuat kesimpulan dan dibantu juga oleh warga belajar dalam membuat kesimpulan, memberikan informasi mengenai materi pembelajaran di pertemuan berikutnya, serta tutor menyiapkan tugas latihan yang dapat dikerjakan oleh peserta didik di luar hari pembelajaran. Pengelolaan kelas, sikap tutor serta cara tutor berkomunikasi saat pembelajaran pun turut mempengaruhi keberhasilan pembelajaran keaksaraan dasar. Dimulai saat pengkondisian warga belajar, yaitu 1) Setiap akan dimulai atau penggantian tema belajar, tutor berkewajiban untuk menjelaskan kepada warga belajar tentang materi yang akan dipelajari, tujuan belajar, proses belajar yang akan dilaksanakan dan hasil belajar yang diharapkan; 2) Menyesuaikan pengaturan tempat duduk peserta didik sesuai dengan tujuan dan proses pembelajaran. Yang biasa dilakukan di kelompok adalah dengan duduk dalam bentuk lingkaran yang memungkinkan warga belajar dapat berinteraksi berhadap-hadapan secara langsung; 3) Menyesuaikan materi pelajaran dengan kecepatan dan kemampuan belajar warga belajar; 4) Memberikan penguatan dan umpan balik terhadap respons serta hasil belajar peserta didik selama pembelajaran berlangsung; 5) Mendorong dan menghargai peserta didik untuk bertanya dan mengemukakan pendapat; 6)
Memulai dan mengakhiri proses pembelajaran sesuai dengan waktu yang dijadwalkan dengan mengacu pada RPP; serta 7) Menghindari kegiatan membosankan yang dapat mengendurkan semangat belajar supaya tidak mengganggu aktivitas dan kreativitas peserta didik.

Pada bagian evaluasi hasil belajar pada pendidikan keaksaraan dasar komunitas adat tertinggal berada dalam kategori "cukup" dengan nilai $\mathrm{P}$ sebesar $76.70 \%$. Nilai ini diperoleh dari perolahan data kuesioner terhadap tutor dan warga belajar. Sedangkan berdasarkan hasil pengolahan data kuesioner bagi tutor, diperoleh nilai $\mathrm{P}$ sebesar $61,88 \%$ yang termasuk ke dalam kategori "cukup" dan bagi warga belajar, diperoleh nilai $\mathrm{P}$ sebesar $86,4 \%$ yang termasuk ke dalam kategori "baik".

Sama halnya dengan pada sub variabel perencanaan, tutor melaksanakan penilaian tetapi pemahaman akan prinsipprinsip penilaian, baik dari tahap perancangan instrumen penilaian, pelaksanaan hingga pelaporan kurang menguasai. Oleh karenanya hasil perolehan data dari kuesioner berada dalam kategori kurang baik untuk indikator pelaksanaan penilaian $(62 \%)$, instrumen penilaian $(67,5 \%)$, dan pelaporan hasil belajar (56\%). Penilaian hasil belajar dilaksanakan pada sepanjang kegiatan pembelajaran secara periodik untuk mengetahui perkembangan belajar warga belajar yang difokuskan pada penilaian berbasis kompetensi yang bertujuan untuk mengukur pencapaian warga belajar dalam memperoleh kompetensi keaksaraan berdasarkan Standar Kompetensi Lulusan (SKL). Penilaian ini dilakukan dengan mengamati tingkat kehadiran peserta didik dan penyelesaian tugas-tugas belajar yang diberikan tutor selama pembelajaran.

Penilaian merupakan proses pengumpulan informasi/bukti tentang 


\section{Diklus: Jurnal Pendidikan Luar Sekolah, 2(2), September 2018 - 126 Aisyah Khoriunnisa}

capaian pembelajaran peserta didik dalam kompetensi sikap, pengetahuan, dan keterampilan yang dilakukan secara terencana dan sistematis selama dan setelah proses pembelajaran. Dalam pembelajaran pendidikan keaksaraan dasar, pendidik harus melakukan penilaian berkenaan dengan:

1) Kompetensi sikap, dapat dilaksanakan dengan cara observasi, penilaian diri, dan jurnal

2) Kompetensi pengetahuan, dapat dilakukan dengan cara Tes tulis, Tes lisan, dan Penugasan; berupa pekerjaan rumah, baik secara individu maupun kelompok sesuai dengan karakteristik tugasnya.

3) Kompetensi keterampilan, dapat dilakukan dengan cara penilaian kinerja, Penilaian projek yaitu dengan pembberian tugas yang harus diselesaikan dalam waktu tertentu, dan/atau portofolio.

Setelah itu seharusnya dapat ditindak lanjuti dengan remedial. Remedial adalah kegiatan untuk mengatasi kesulitan belajar yang bertujuan untuk membantu peserta didik yang mengalami kesulitan atau belum tuntas menguasai kompetensi yang telah ditentukan. Cara berikutnya adalah dengan pengayaan. Pengayaan adalah kegiatan yang diberikan kepada peserta didik yang telah menyelesaikan ketuntasan belajar untuk menambah pengetahuan dan keterampilan, baik secara individu maupun kelompok yang dapat dilakukan dengan memberikan tugas-tugas (membaca, menulis, dan berhitung).

Berdasarkan data kehadiran yang dimiliki oleh tutor, dapat disampaikan bahwa tingkat kehadiran peserta didik keseluruhan rata-ratanya adalah $84 \%$. Kelompok belajar dengan tingkat kehadiran tertingi adalah kelompok belajar Jampana yaitu sebesar $87 \%$ sedangkan kelompok belajar dengan tingkat kehadiran terendah adalah kelompok belajar Awug dengan tingkat kehadiran sebesar 81.Berdasarkan temuan peneliti, pada setiap akhir pembelajaran, tutor melakukan penilaian terhadap penguasaan kompetensi membaca, menulis dan berhitung warga belajar tetapi sayang sekali tidak ditindak lanjuti dengan melaksanakan remedial/perbaikan materi belajar.

Seperti yang sudah disampaikan sebelumnya bahwa penilaian akhir dilakukan untuk mengetahui ketercapaian kompetensi lulusan keaksaraan dasar oleh peserta didik. Aspek yang dinilai meliputi kemampuan membaca, menulis dan berhitung dalam Bahasa Indonesia dan bahasa Cacarakan. Penilaian akhir dilakukan oleh tim pelaksana ujian akhir yang dibentuk oleh Dinas Pendidikan Kota Cimahi, yang melibatkan tenaga fungsional pamong belajar pada UPTD Dinas Pendidikan Kota Cimahi.

Pada bagian Sub variabel pelaksanaan kurikulum pendidikan keaksaraan dasar komunitas adat tertinggal berada dalam kategori cukup dengan nilai $P$ sebesar $75.68 \%$. Nilai ini diperoleh dari perolahan data kuesioner terhadap tutor dan warga belajar. Ornstein \& Hunskin (2017, hlm. 257) menyebutkan bahwa keberhasilan implementasi kurikulum dihasilkan dari perencanaan yang matang dan berfokus pada tiga faktor yaitu orang, program, dan proses. Untuk menerapkan perubahan kurikulum, pendidik harus membuat orang mampu mengubah beberapa kebiasaan mereka dan bahkan pandangannya terhadap perubahan. Banyak sekolah gagal melaksanakan program baru karena mengabaikan faktor "orang" dan menghabiskan waktu dan uang dengan hanya memodifikasi program atau proses. Namun, berfokus pada program baru memberikan cara baru untuk memenuhi tujuan program sekolah. Pengorganisasian orang-orang yang terlibat dalam implementasi juga penting, karena dapat menggerakkan mereka ke 


\section{Diklus: Jurnal Pendidikan Luar Sekolah, 2(2), September 2018 - 127 Aisyah Khoriunnisa}

arah yang diperlukan agar implementasi kurikulum sukses.

Dalam hal pengorganisasian, pengelola terutama tokoh adat atau tetua yang ada di Masyarakat Adat Cireundeu sudah menyadari akan perlunya pendidikan aksara bagi warga adatnya terutama untuk warga adat yang buta aksara. Hal ini didasari pula semakin bertambahnya frekuensi kunjungan dari luar masyarakat adat yang tertarik untuk melakukan kunjungan budaya masyarakat Cireundeu. Menurut penuturan tetua disana, yaitu Abah Asep dan Abah Emen bahwa semakin banyak warga adat yang bisa menyambut tamu dengan ramah menggunakan Bahasa Indonesia akan semakin baik. Kemudian, semakin banyak warga adat yang bisa bertutur dan menceritakan sejarah dari masyarakat adat Cireundeu dengan baik akan semakin baik bagi pelestarian Masyarakat Adat. Dukungan pengelola dalam penyelenggaraan program pendidikan keaksaraan dasar di komunitas adat tertingal terutama yang diperoleh dari tetua di masyarakat adat Cireundeu merupakan salah satu bukti nyata bahwa pembelajaran keaksaraan dasar ini didukung sepenuhnya. Hal ini didukung dengan hasil survey untuk aspek dukungan pengelola sebesar $76,4 \%$ dan termasuk ke dalam kategori cukup.

Dalam Permendikbud No. 86 Tahun 2014 menyebutkan kriteria dan persyaratan pendidik dan tenaga kependidikan pendidikan keaksaraan dasar. Berdasarkan data hasil temuan wawancara kepada pengelola, terdapat beberapa penyesuaian terhadap beberapa kriteria di atas. Kualifikasi pendidik, tiga orang diantaranya merupakan lulusan SMP. Tetapi dikarenakan tutor tersebut memiliki kompetensi keaksaraan dasar sesuai dengan tujuan pembelajaran maka dilakukan penyesuaian. Pengelola lebih menitikberatkan kepada kompetensi tutor yang harus lebih banyak dikuasai. Seperti terdapat pada jawaban wawancara terhadap pengelola bahwa dalam proses seleksi calon tutor dinyatakan tutor dipilih berdasarkan kemampuannya dalam bertutur atau bercerita tentang sejarah masyarakat adat Cireundeu.

Pengembangan implementasi kurikulum pada dasarnya dimaksudkan sebagai upaya-upaya memaksimalkan pelaksanaan kurikulum untuk meningkatkan hasil belajar peserta didik. Dalam penerapannya (dalam bentuk proses belajar mengajar atau proses pendidikan dan latihan), pelaksana kurikulum (guru, kepala sekolah, serta manajemen sekolah) dapat melakukan perubahan (modification), penyesuaian (adaptation), atau pembaharuan (innovation) berdasarkan kondisi, kebutuhan, dan tuntutan setempat. Upaya modifikasi, adaptasi dan inovasi kurikulum adalah faktor penting karena sebuah kurikulum tidak akan pernah dapat diimplementasikan sesuai desain awal sehingga perlu dilakukan penyesuaian-penyesuaian untuk memperoleh hasil secara maksimal. Ukuran kesuksesan sebuah implementasi kurikulum dapat dilihat dari sejauh mana pengembang kurikulum memiliki kemampuan dan kemauan untuk mengakomodasi kemungkinan dilakukannya modifikasi dalam kurikulum (Wahyudin, 2014, hlm. 94).

Faktor pendidik atau guru atau tutor sebagai pelaksana implementasi kurikulum harus dapat menerima perubahan terlebih dahulu sebelum melakukan perubahan kurikulum di kelas masing-masing. Ketika kepala satuan pendidikan berhasil mengidentifikasi kesulitan guru dalam menerima perubahan, maka dia harus segera mencarikan solusi sehingga diharapkan guru menjadi lebih percaya diri dalam mengimplementasikan kurikulum tersebut kepada peserta didik. Dampaknya pun adalah peserta didik dapat merasakan dampak positif dari perubahan kurikulum tersebut 
(Ornstein\&Hunkins, 2017 dan Ansyar, 2015).

\section{PENUTUP}

dalam $\begin{gathered}\text { Implementasi } \\ \text { kategori }\end{gathered} \begin{aligned} & \text { kurikulum berada } \\ & \text { cukup. Artinya, }\end{aligned}$ implementasi kurikulum pada Komunitas Adat Tertinggal di masyarakat adat Cireundeu telah dinyatakan cukup impelementatif serta telah merujuk kepada Permendikbud No. 86 Tahun 2014 tentang Pedoman Penyelenggaraan Pendidikan Keaksaraan Dasar. Secara khusus, implementasi kurikulum ditinjau pada setiap tahap, yaitu tahap perencanaan, pelaksanaan, dan evaluasi hasil belajar.

Implementasi kurikulum yang ditinjau pada tahap perencanaan termasuk ke dalam kategori kurang. Tahap perencanaan merupakan tahap penting dalam implementasi kurikulum. Peranan tutor dan pengelola dalam tahapan ini berperan besar, dengan tetap mengacu kepada Permendikbud No. 86 Tahun 2014 tentang Pedoman Penyelenggaraan Pendidikan Keaksaraan Dasar serangkaian langkah-langkah perencanaan telah dilakukan namun dengan keterbatasan pengetahuan dan pengalaman tutor dalam merencanakan terutama dalam penyusunan silabus dan RPP.

Implementasi kurikulum pada tahap pelaksanaan kegiatan pembelajaran berada dalam kategori cukup. Dalam pelaksanaan pembelajaran terdapat komponen-komponen yang bisa mendukung pencapaian tujuan dari pembelajaran. Pertama, metode yang digunakan dalam pembelajaran. Kedua, bahan dan media belajar serta teknik yang dipergunakan dalam pembelajaran. Ketiga, kegiatan-kegiatan yang dilakukan untuk menghindari kejenuhan dalam pembelajaran. Pada sub variabel ini indikator identifikasi dengan penilaian awal, kegiatan pembukaan pembelajaran, dan pemanfaatan sumber dan media/ alat pembelajaran memperoleh kategori baik.
Indikator kesesuaian pelaksanaan pembelajaran dengan RPP dan indikator penutup pembelajaran memperoleh kategori cukup. Indikator Pengelolaan kegiatan inti yang disesuaikan dengan pendidikan keaksaraan dan indikator penguasaan dan kesesuaian materi pelajaran berada dalam kategori "kurang". Hal ini merupakan dampak dari kurangnya pengetahuan tutor dalam menyusun rencana pembelajaran, sehingga dalam pelaksanaannya tutor terkadang tidak menjalankannya sesuai dengan rencana pembelajaran serta untuk pengelolaan kegiatan inti yang kurang bisa menggabungkan antara materi ajar yang sudah sangat baik disusun hanya pada pelaksanaannya gagal dalam menyesuaikan dengan karakteristik pendidikan keaksaraan.

Implementasi kurikulum yang ditinjau dari tahap evaluasi hasil belajar berada dalam kategori cukup. Pada tahap ini, baik pada indikator pelaksanaan, penyusunan instrument evaluasi, serta pelaporan bagi responden tutor berada pada kategori kurang sedangkan bagi responden warga belajar berada dalam kategori baik. Hal ini cukup bertolak belakang apabila ditinjau dari kedua responden. Hal ini bisa saja disebabkan oleh warga belajar yang merasa puas dalam mengikuti pendidikan keaksaraaan yang diakhiri dengan kelulusan sepenuhnya untuk aksara Bahasa Indonesia serta memperoleh kesempatan untuk belajar aksara Cacarakan.

Implementasi kurikulum yang ditinjau dari faktor pendukung dan penghambat implementasi kurikulum pendidikan keaksaraan dasar komunitas adat tertinggal berada dalam kategori cukup. Pada umumnya faktor pendukung baik internal maupun eksternal berada dalam kategori baik. Selain perolehan data kuesioner, didukung juga oleh hasil wawancara terhadap pengelola pendidikan keaksaraan dasar. Kesulitan atau kendala yang dihadapi pada tahap perencanaan 
dapat diatasi dengan meminta bantuan pelatihan kepada orang yang lebih ahli dalam penyusunan kurikulum dan perangkatnya. Ide ini digagas oleh pengelola serta disambut baik oleh pihak Unit Pelaksana Teknis Daerah (UPTD) Sanggar Kegiatan Belajar (SKB) Kota Cimahi. Hal ini menunjukan salah satu dukungan pengelola dalam pelaksanaan pendidikan keaksaraan.

\section{DAFTAR PUSTAKA}

Ansyar, M. (2015). Kurikulum hakikat, fondasi, desain dan pengembangan. Jakarta: Prenadamedia Group.

Asghary, N.; Shahvarani, A.; Medghlmchi' A. R. (2013). Significant Process of Change For Elementary Teachers To Foster Functional Thinking. Bolema Vol. $27 \quad$ (47) http://dx.doi.org/10.1590/S0103636X2013000400015

Bahua, M. I. (2015). Model Pengembangan Pemberdayaan Masyarakat Komunitas Adat Terpencil (KAT) Di Kabupaten Boalemo. Jurnal Pendidikan, Sosial, dan Budaya Ideas vol 01 (2) pp. 278-294

Basrowi dan Suwandi. (2008). Memahami Penelitian Kualitatif. Jakarta: Rineka Cipta.

Bogdan, R.C \& Biklen, S.K. (1982). Qualitative Research for Education, an Introduction to Theory and Methods $\left(2^{\text {nd }}\right.$ edition $)$. Needham Heights: Allyn and Bacon.

Creswell, J.W. (2016). Research Design: Pendekatan Metode Kualitatif, Kuantitatif, fan Campuran. (Edisi Keempat). Yogyakarta: Pustaka Pelajar.
Coombs, P. (1985). The World Crisis in Education. New Yor : Oxford University Press.

Dinas Pariwisata dan Budaya Provinsi Jawa Barat. [online]. Diakses dari http://www.disparbud.jabarprov.go.i d pada tanggal 3 Januari 2018.

Direktorat Pembinaan Pendidikan Keaksaraan dan Kesetaraan. (2017). Paparan Kebijakan Pendidikan Keaksaraan pada Bimbingan Teknis Pembelajaran dan Penyelenggaraan Keaksaraan Dasar Komunitas Adat Terpencil/Khusus (KD-KAT)

Hasan, S. H. (2007). Pengembangan KTSP dalam Ilmu dan Aplikasi Pendidikan. Bandung: Pedagogiana.

Hasibuan, J. (2017). Implementasi Pembelajaran Berbasis Budaya Lokal Dalam Meningkatkan Kesejahteraan Masyarakat. S2 thesis, Universitas Pendidikan Indonesia.

Hamalik, O. (1995). Kurikulum dan Pembelajaran. Jakarta: Bumi Aksara.

Hanemann, U., dkk., (2017). Learning Together Across Generations, Guidelines for Family Literacy and Learning Programmes. UNESCO.

Kamil, M. (2009). Pendidikan Nonformal. Bandung: Alfabeta.

Kusnadi. (2005). Pendidikan Keaksaraan Filosofi, Strategi, Implementasi. Jakarta: Direktorat Jenderal Pendidikan Luar Sekolah.

Longworth, N. (2003). Lifelong Learning in Action. London: London \& Sterling, VA.

Mahu, S. (2011). Pengembangan Model Pembelajaran Keaksaraan Fungsional 
Berbasis Potensi Lokal Pertanian Bagi Pemberdayaan Komunitas Adat Terpencil : studi di Kecamatan Waiapo Kabupaten Buru). S3 thesis, Universitas Pendidikan Indonesia

Marwoto, S. (tt). Buku Saku Pendidikan Keaksaraan. [online]. Diakses dari https://www.slideshare.net/su7ud/b uku-saku-pendidikan-keaksaraan pada tanggal 5 Desember 2017

Mc.Neil, J. D. (2006). Contemporary Curriculum In Thought And Action, Sixth Edition. New Jersey: Willey Jossey - Bass Education

Miller, J. P. \& Seller, W. (1985). Curriculum perspectives and practice. New York: Longman.

Miller-Day, M, dkk. (2013). How Prevention Curricula Are Taught Under Real-World Conditions, Types of and Reasons for Teacher Curriculum Adaptations. Health Education Vol. 113 (4) pp. 324-344 http://dx.doi.org/10.1108/0965428131 1329259

Moleong, Lexy J. (2015). Metodologi Penelitian Kualitatif. Edisi Revisi. Bandung: Remaja Rosdakarya.

Nurdin, S. \& Adriantoni. (2016). Kurikulum dan Pembelajaran. Jakarta: Rajawali Pers.

Ornstein, A.C. \& Hunkins, F.P. (2017). Curriculum, Foundations, Principles, and issues. Seventh Ed. England : Pearson Education.

Permendikbud No. 86 Tahun 2014 tentang Pedoman Penyelenggaraan Pendidikan Keaksaraan Dasar.

Piliang, Z. 2006. Kejar Paket C. [online]. Diakses dari https://arifsulistyo.wordpress.com/j urusan-pls/kejar-paket-c/ pada tanggal 25 Maret 2013

Rogers, A. (1993). Non Formal Educatioan, flexible sbhooling or participatory education?. Hong Kong: Kluwer Academic Publisher.

Rusman. (2009). Manajemen Kurikulum. Jakarta: Rajawali Pers.

Sanjaya, W. (2015). Kurikulum dan pembelajaran teori dan praktik pengembangan kurikulum tingkat satuan pendidikan (KTSP). Jakarta: Prenadamedia Group.

Saylor, J G; Alexander W M; \& Lewis, A J;. (1981). Curriculum Planning For Better Teaching and Learning. New York: Holt, Rinehart and Winston.

Sugiyono. (2013). Metode Penelitian Kuantitatif, Kualitatif Dan $R \& D$ (Cetakan Ke-13). Bandung: Penerbit Alfabeta.

Sumiati, $\quad$ Ema. (2015). Model Pemberdayaan Masyarakat Dalam Mempertahankan Kearifan Lokal : Etnografi Pada Masyarakat Adat Kampung Cireundeu Kota Cimahi. S2 thesis, Universitas Pendidikan Indonesia.

Sumiati, E. dan Hufad, A. (2016). study of Indigenouse Peoples Empowerment Model in Sundanese Village. Prosiding $1^{\text {st }}$ UPI International Conference on Sociology Education (UPI ICSE 2015) Bandung: Atlantis Press.

Susilana, R. \& Rusman. (2015). Implementasi Kurikulum 2013 Di Sekolah Dasar. Edutech Vol.1 (1) p. 52-67

Sutisna, A. (2016) Pengembangan Model Pembelajaran Blended pada 
Pendidikan Kesetaraan Paket $C$ Dalam Meningkatkan Kemandirian Belajar. Jurnal Teknologi Pendidikan Vol. 18 (3) p. 156-168.

Suwarno, E, M. S. (2008). Etnografi Komunikasi. Bandung: Widya Padjadjaran.

Talan, C. (2001). Family literacy: an investment in the future. The Bottom Line, Vol. 14 (1) pp. 12 18

http://dx.doi.org/10.1108/0888045 0110364895

Tilaar, H.A.R. (1999). Pendidikan Kebudayaan dan Masyarakat Madani Indonesia. Bandung: Remaja Rosdakarya.

Undang-Undang Dasar Republik Indonesia Tahun 1945

Undang-Undang Republik Indonesia No. 20 Tahun 2003 tentang Sistem Pendidikan Nasional

Wahyudin, D. (2014). Manajemen Kurikulum. Bandung: PT. Remaja Rosdakarya.

Zais, R. S. (1976). Curriculum Principle and Foundations. New York: Thomas Y. Crowll Company, Inc. 